\title{
Pengaruh Promosi dan Harga Terhadap Keputusan Pembelian Kalkulator Merek Casio Pada Toko Citra Pasar Senen Di Jakarta Pusat
}

\author{
Sugeng Widodo ${ }^{*}$, Cecep Efendi ${ }^{2}$, Gatot Kusjono3 \\ 1,2Fakultas Ekonomi, Universitas Pamulang; doseno1632@unpam.ac.id* \\ 3Fakultas Ekonomi Universitas Pamulang; dosen0434@unpam.ac.id
}

\begin{abstract}
Abstrak
Tujuan penelitian untuk mengetahui pengaruh promosi dan harga terhadap keputusan pembelian kalkulator Casio. Metode yang digunakan bersifat asosiatif pendekatan kuantitatif. Metode analisis yang dipakai adalah uji validitas, uji reliabilitas, uji regresi linier sederhana, uji koefisien korelasi, uji koefisien determinasi, dan uji t. Hasil uji parsial diperoleh bahwa promosi tidak berpengaruh terhadap keputusan pembelian sedangkan harga berpengaruh terhadap keputusan pembelian. Secara simultan promosi dan harga tidak berpengaruh terhadap keputusan pembelian dengan nilai signifikansi 0,717 > 0,05.
\end{abstract}

Kata Kunci: Promosi; Harga; Keputusan Pembelian

\begin{abstract}
The research objective was to determine the effect of promotion and price on purchasing decisions of Casio calculators. The method used is an associative quantitative approach. The analysis method used is the validity test, reliability test, simple linear regression test, correlation coefficient test, determination coefficient test, and $t$ test. The partial test results show that promotion has no effect on purchasing decisions while price affects purchasing decisions. Simultaneously promotion and price have no effect on purchasing decisions with a significance value of $0.717>0.05$.
\end{abstract}

Keywords: Promotion; Price; Purchase Decision

*) Korespondensi penulis 


\section{PENDAHULUAN}

Persaingan dalam dunia bisnis semakin ketat, membuat perusahaan berusaha mencari strategi yang cepat dan tepat dalam memasarkan produknya. Dalam era globalisasi menuntut perusahaan harus mampu bersikap dan bertindak cepat dan tepat dalam menghadapi persaingan dilingkungan bisnis yang bergerak sangat dinamis dan penuh dengan ketidak pastian. Oleh karena itu, setiap perusahaan dituntut bersaing secara kompetitif dalam hal strategi bisnis untuk mencapai tujuan perusahaan serta memahami apa yang terjadi dipasar dan apa yang menjadi keinginan konsumennya.

Mengingat tingkat persaingan yang semakin ketat, maka pihak perusahaan harus meningkatkan pelayanan, untuk membangun hubungan jangka panjang dengan pelanggan atau calon pelanggan lainnya. Melalui promosi perusahaan dapat memperkenalkan produk yang dihasilkan kepada masyarakat, sehingga masyarakat dapat mengetahui produk yang telah diproduksi. Namun, akibat dari banyaknya pemain dalam dunia bisnis ini, terjadi persaingan yang tinggi, untuk dapat menjaga posisinya dan bertahan, perusahaan harus memahami karakteristik konsumen mereka dan memahami bagaimana konsumen dalam memutuskan pembelian. Sehingga dengan memahami perilaku konsumen dalam proses pengambilan keputusan, maka perusahaan akan dapat mempengaruhinya, sehingga konsumen tersebut nantinya akan menggunakan produk mereka. Menurut Herly Birgays (2009:4) menyatakan bahwa "proses pengambilan keputusan pembelian terdiri dari lima tahap: pengenalan kebutuhan, pencarian informasi, pengevaluasian alternatif, keputusan pembelian dan perilaku setelah pembelian".

Berkaitan keputusan pelanggan dalam memilih produk kalkulator pada
Toko Kalkulator Casio di Toko Citra Pasar Senen di Jakarta Pusat sangat ditentukan oleh promosi dan harga dari produk tersebut. Menurut Kotler dan Armstrong (2014:77) "promosi adalah aktivitas yang mengkomunikasikan keunggulan produk dan membujuk pelanggan untuk membeli produk itu". Selain itu, Kotler dan Amstrong (2012:314) menjelaskan "ada empat ukuran yang mencirikan harga, adalah keterjangkauan harga, kesesuaian harga dengan kualitas, kesesuaian harga dengan manfaat, dan harga sesuai kemampuan atau daya beli”.

Sebagai toko yang bergerak dalam penjualan kalkulator dengan banyaknya pesaing sehingga menuntut Toko Citra Pasar Senen di Jakarta Pusatmelakukan promosi, saat ini Toko Citra Pasar Senen di Jakarta Pusatsudah melakukan berbagai promosi seperti pemasaran langsung melalui sales dengan harapan bahwa konsumen akan melakukan pembelian terhadap kalkulator casio. Berikut kegitan promosi yang telah dilakukan.

Tabel 1.Promosi yang dilakukan Toko
Citra Pasar Senen di Jakarta Pusat
\begin{tabular}{|c|l|c|c|c|c|c|}
\hline No & $\begin{array}{l}\text { Promosi yang Telah } \\
\text { di Lakukan }\end{array}$ & \multicolumn{5}{|c|}{ Tahun } \\
\hline 1. & $\begin{array}{l}\text { Personal } \\
\text { Selling } \\
\text { (Penjualan } \\
\text { Langsung) }\end{array}$ & $\times$ & v & v & $\times$ & v \\
\hline 2. & $\begin{array}{l}\text { Advertising } \\
\text { (Periklanan) }\end{array}$ & $\times$ & $\times$ & $\times$ & $\times$ & $\times$ \\
\hline $3 \cdot$ & $\begin{array}{l}\text { Sales } \\
\text { Promotion } \\
\text { (Promosi } \\
\text { Penjualan) }\end{array}$ & $\times$ & v & v & v & v \\
\hline $4 \cdot$ & $\begin{array}{l}\text { Public Relation } \\
\text { (Publisitas) }\end{array}$ & $\mathrm{v}$ & $\times$ & $\mathrm{v}$ & $\times$ & $\mathrm{v}$ \\
\hline 5. & $\begin{array}{l}\text { Direct } \\
\text { Marketing } \\
\text { (Pemasaran } \\
\text { Langsung) }\end{array}$ & $\mathrm{v}$ & $\mathrm{v}$ & $\mathrm{v}$ & $\mathrm{v}$ & $\mathrm{v}$ \\
\hline
\end{tabular}
Sumber : Data Toko Citra Pasar Senen di Jakarta Pusat
(2019)

Data di atas, menunjukkan bahwa Toko Citra Pasar Senendi Jakarta Pusat melakukan promosi Personal Selling (Penjualan Langsung) namun belum maksimal di lakukan langsung ke 
konsumen,Advertising (Periklan) Toko Citra Pasar Senendi Jakarta Pusat tidak pernah melakukan promosi periklanan selama kurun waktu 5 tahun terakhir, namun Toko Citra Pasar Senendi Jakarta Pusat telah melakukan promosi lainnya seperti Sales Promotion ( Promosi Penjualan ), Public Relation ( Publisitas), Direct Marketing (Pemasaran Langsung) namun promosi yang dilakukan belum maksimal sehingga perlu di tingkatkan. Untuk meningkatkan keputusan pembelian terhadap Kalkulator Casio Toko Citra Pasar Senendi Jakarta Pusatperlu memperhatikan unsur penting dalam stategi promosi terdiri dariperiklanan, promosi penjualan, publisitas dan pemasaran langsung. Promosi itu sendiri adalah proses mengkomunikasikan variabel bauran pemasaran (marketing mix) yang sangat penting dilakukan oleh perusahaan dalam memasarkan produknya menurut Ali Hasan (2013:603).

Selain promosi yang baik, harga produk merupakan salah satu alasan konsumen memililh suatu produk. Berikut daftar harga produk kalkulator Casio pada Toko Citra Pasar Senendi Jakarta Pusat.

\begin{tabular}{|c|c|c|c|c|c|}
\hline \multicolumn{6}{|c|}{ Tabel 2. Harga Kalkulator Casio Toko Citra Pasar Senen di Jakarta Pusat } \\
\hline No & Tipe & Nama & Harga & Picture & $\begin{array}{c}\text { Minat } \\
\text { Konsumen }\end{array}$ \\
\hline 1 & MX-12B & $\begin{array}{l}\text { CC.PC MX-12B-WE- } \\
\text { W-DC }\end{array}$ & Rp. 76000 & & $74 \%$ \\
\hline 2 & $\begin{array}{l}\text { MJ-12ODPLUS } \\
\text { Black }\end{array}$ & $\begin{array}{l}\text { CC.PC MJ- } \\
\text { 12ODPLUS- } \\
\text { BKWDPW }\end{array}$ & Rp. 146.000 & & $60 \%$ \\
\hline 3 & DJ-120DPLUS & $\begin{array}{c}\text { CC.PC DJ- } \\
\text { 120DPLUS-WA- } \\
\text { DPW }\end{array}$ & Rp. 193.000 & & $82 \%$ \\
\hline 4 & SX-320P & $\begin{array}{c}\text { CC.PC SX-320P-W- } \\
\text { DP }\end{array}$ & Rp. 64.000 & 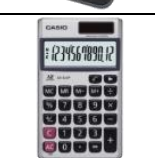 & $44 \%$ \\
\hline 5 & FX-991IDPLUS & $\begin{array}{c}\text { CC.SC FX- } \\
\text { 991IDPLUS-W-DT }\end{array}$ & Rp. 296.000 & & $79 \%$ \\
\hline
\end{tabular}

Sumber : Catalog Casio (2019)

Tabel di atas menunjukkan adanya perbedaan harga di tiap tipe kalkulator casio walaupun dengan segmen yang sama, dengan tipe $\mathrm{MX}-12 \mathrm{~B}$ memiliki minat konsumen mengunakannya sebesar $74 \%$ hal di ini disebab oleh harga kalkulator yang terjangkau, dengan Tipe MJ-12O DPLUS Black di angka 60\% hal ini disebabkan oleh harga yang sesuai dengan kualitas produk dan di lengkapi dengan sistem check, TipeDJ-120DPLUS diminati sebesar $82 \%$ hal ini disebabkan oleh bentuk kalkulator yang besar sehingga mem- permudah konsumen dalam menghitung, dengan TipeSX-320P sebesar 44\% minat konsumen hal ini disebabkan oleh model kalkulator lipat yang mudah di simpan di saku sehingga konsumen melakukan keputusan pembelian, untuk tipeFX-991 IDPLUS sebesar 79\% minat konsumen di karenakan harga yang sesuai dengan kualitas yang baik sehingga konsumen memutuskan untuk membeli produk Kalkulator Casio.

Penelititian ini untuk menganalisis Pengaruh Promosi dan Harga Terhadap 
Keputusan Pembelian Kalkulator Merek Casio pada Toko Citra Pasar Senen di Jakarta Pusat

\section{Kerangka Berpikir}

Kerangka berfikir dalam penelitian ini seperti ditunjukkan pada gambar berikut:

Promosi (Variabel X1)

1. Produk

2. Harga

3. Tempat

4. Promosi

Sumber :Kotler dan Armstrong (2014:77)

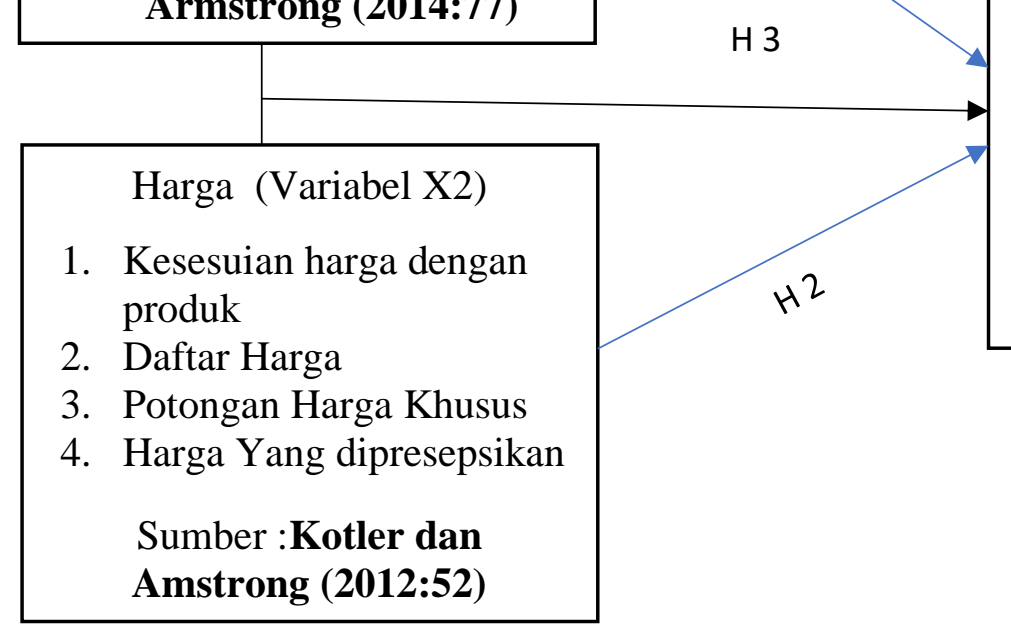

Keputusan Pembelian (Variabel Y)

1. Pengenalan Kebutuhan

2. Pencarian Informasi

3. Evaluasi Alternatif

4. Keputusan Pembelian

5. Perilaku Setelah pembelian

\section{Sumber :Herly Birgays} (2009:4)

\section{Gambar 1. Kerangka Berfikir}

\section{METODE}

Metode yang digunakan dalam penelitian ini deskriptif kualitatif dengan mengambil sampel secara random sebanyak 100 pelanggan yang membeli kalkulator Kasio pada Pasar Senen Jakarta Pusat. Data yang diolah berupa data primer yang diisi oleh pelanggan. Kemudian data tersebut diolah dan dianalisa dengan menggunakan alat bantu aplikasi SPSS Versi 22. Sehingga dapat dijadikan dasar pengambilan keputusan.Tujuan metode analisis data adalah untuk menginterprestasikan dan menarik kesimpulan dari sejumlah data yang terkumpul.

\section{HASIL dan PEMBAHASAN \\ Hasil Uji Validitas}

Tabel 3. Uji Validitas Promosi $\left(X_{1}\right)$

\begin{tabular}{|cl|c|c|c|}
\multicolumn{2}{|c|}{$\begin{array}{c}\text { Item } \\
\text { Kuisioner }\end{array}$} & $\begin{array}{c}\text { Nilai r } \\
\text { hitung }\end{array}$ & $\begin{array}{c}\text { Nilai r } \\
\text { tabel }\end{array}$ & Keputusan \\
\hline 1. & PM-1 & 0,433 & 0,197 & Valid \\
\hline 2. & PM-2 & 0,288 & 0,197 & Valid \\
\hline 3. & PM-3 & 0,218 & 0,197 & Valid \\
\hline 4. & PM-4 & 0,328 & 0,197 & Valid \\
\hline 5. & PM-5 & 0,295 & 0,197 & Valid \\
\hline 6. & PM-6 & 0,481 & 0,197 & Valid \\
\hline 7. & PM-7 & 0,336 & 0,197 & Valid \\
\hline 8. & PM-8 & 0,579 & 0,197 & Valid \\
\hline 9. & PM-9 & 0,323 & 0,197 & Valid \\
\hline 10. & PM-10 & 0,558 & 0,197 & Valid \\
\hline 11. & PM-11 & 0,579 & 0,197 & Valid \\
\hline 12. & PM-12 & 0,323 & 0,197 & Valid \\
\hline 13. & PM-13 & 0,558 & 0,197 & Valid \\
\hline
\end{tabular}

Hasi uji validitas diperoleh seluruh item pertanyaan variabel promosi $\left(\mathrm{X}_{1}\right)$ nilai koefisien korelasi di atas 0.197 sehingga seluruh item angket variabel promosi $\left(\mathrm{X}_{1}\right)$ adalah Valid. 
Tabel 4. Uji Validitas "Harga” $\left(X_{2}\right)$

\begin{tabular}{|cc|c|c|c|}
\hline \multicolumn{2}{|c|}{$\begin{array}{c}\text { Item } \\
\text { Kuisioner }\end{array}$} & $\begin{array}{c}\text { Nilai r } \\
\text { hitung }\end{array}$ & $\begin{array}{c}\text { Nilai r } \\
\text { tabel }\end{array}$ & Keputusan \\
\hline 1. & HG-1 & 0,273 & 0,197 & Valid \\
\hline 2. & HG-2 & 0,405 & 0,197 & Valid \\
\hline 3. & HG-3 & 0,380 & 0,197 & Valid \\
\hline 4. & HG-4 & 0,361 & 0,197 & Valid \\
\hline 5. & HG-5 & 0,333 & 0,197 & Valid \\
\hline 6. & HG-6 & 0,477 & 0,197 & Valid \\
\hline 7. & HG-7 & 0,340 & 0,197 & Valid \\
\hline 8. & HG-8 & 0,335 & 0,197 & Valid \\
\hline 9. & HG-9 & 0,318 & 0,197 & Valid \\
\hline 10. & HG-10 & 0,385 & 0,197 & Valid \\
\hline 11. & HG-11 & 0,304 & 0,197 & Valid \\
\hline 12. & HG-12 & 0,212 & 0,197 & Valid \\
\hline 13. & HG-13 & 0,364 & 0,197 & Valid \\
\hline 14. & HG-14 & 0,405 & 0,197 & Valid \\
\hline 15. & HG-15 & 0,364 & 0,197 & Valid \\
\hline
\end{tabular}

Hasi uji validitas diperoleh seluruh item pertanyaan variabel harga $\left(\mathrm{X}_{2}\right)$ nilai koefisien korelasi di atas 0.197 sehingga seluruh item angket variabel harga $\left(\mathrm{X}_{2}\right)$ adalah Valid.

Tabel 5. Uji Vaditas

Keputusan Pembelian (Y)

\begin{tabular}{|cc|c|c|c|}
\multicolumn{6}{|c|}{$\begin{array}{c}\text { Item } \\
\text { Kuisioner }\end{array}$} & $\begin{array}{c}\text { Nilai r } \\
\text { hitung }\end{array}$ & $\begin{array}{c}\text { Nilai r } \\
\text { tabel }\end{array}$ & Keputusan \\
\hline 1. & KP-1 & 0,605 & 0,197 & Valid \\
\hline 2. & KP-2 & 0,528 & 0,197 & Valid \\
\hline 3. & KP-3 & 0,480 & 0,197 & Valid \\
\hline 4. & KP-4 & 0,344 & 0,197 & Valid \\
\hline 5. & KP-5 & 0,527 & 0,197 & Valid \\
\hline 6. & KP-6 & 0,458 & 0,197 & Valid \\
\hline 7. & KP-7 & 0,478 & 0,197 & Valid \\
\hline 8. & KP-8 & 0,662 & 0,197 & Valid \\
\hline 9. & KP-9 & 0,366 & 0,197 & Valid \\
\hline 10. & KP-10 & 0,443 & 0,197 & Valid \\
\hline 11. & KP-11 & 0,233 & 0,197 & Valid \\
\hline 12. & KP-12 & 0,302 & 0,197 & Valid \\
\hline
\end{tabular}

Hasi uji validitas diperoleh seluruh item pertanyaan variabel keputusan pembelian (Y) nilai koefisien korelasi di atas 0.197 sehingga seluruh item angket variabel keputusan pembelian (Y) adalah Valid.

\section{Uji Reliabilitas}

Uji Reliabilitas digunakan untuk mengukur tingkat kekonsistenan tanggapan responden terhadap item pernyataan angket berdasarkan pemahaman responden terhadap pertanyaan-pertanyaan dalam kuesioner.
Tabel 6. Hasil Pengujian Reliabilitas

\begin{tabular}{|c|l|c|c|c|}
\hline No & Variabel & $\begin{array}{c}\text { Cronbach's } \\
\text { Alpha }\end{array}$ & $\begin{array}{c}\text { Nilai } \\
\text { Standar }\end{array}$ & Ket \\
\hline $\mathbf{1}$ & Promosi & 0,576 & 0,30 & Reliabel \\
\hline $\mathbf{2}$ & Harga & 0,682 & 0,30 & Reliabel \\
\hline 3 & $\begin{array}{l}\text { Keputusan } \\
\text { Pembelian }\end{array}$ & 0,686 & 0,30 & Reliabel \\
\hline
\end{tabular}

Sumber : Data diolah dengan SPSS versi 22

Hasil uji diperoleh nilai Alpha> 0.30, Artinya seluruh data reliabel.

\section{Uji Asumsi Klasik}

Uji Normalitas, Pengujian normalitas yang digunakan yaitu dengan melihat grafik histogram dan P-P Plot.

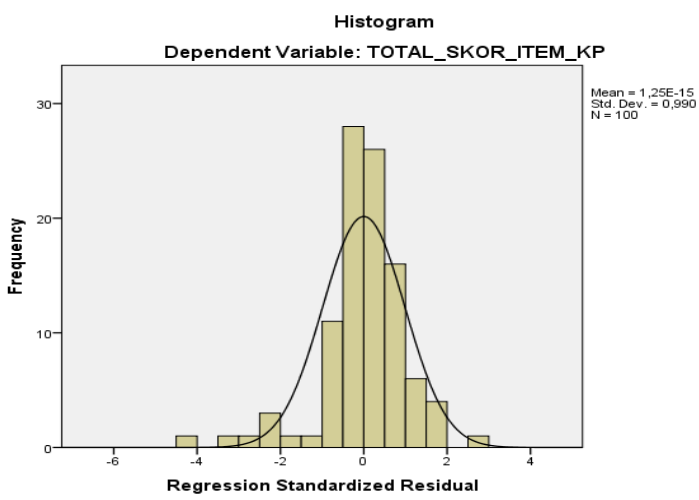

\section{Gambar 2. Hasil Uji Normalitas Menggunakan Histogram}

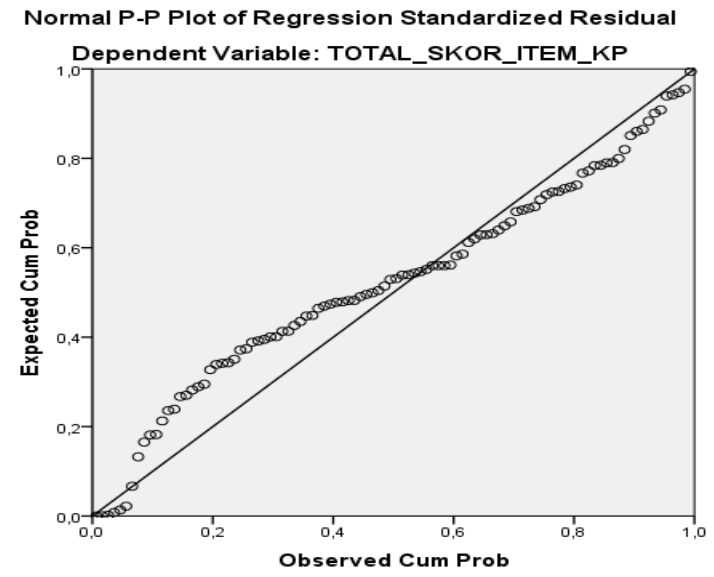

Gambar 3. Hasil Uji Normalitas Menggunakan Grafik P-Plot

Berdasarkan grafik di atas, sebaran residu data berada di sekitar garis diagonal, artinya data terdistribusi normal. 


\section{Uji Heteroskedastisitas}

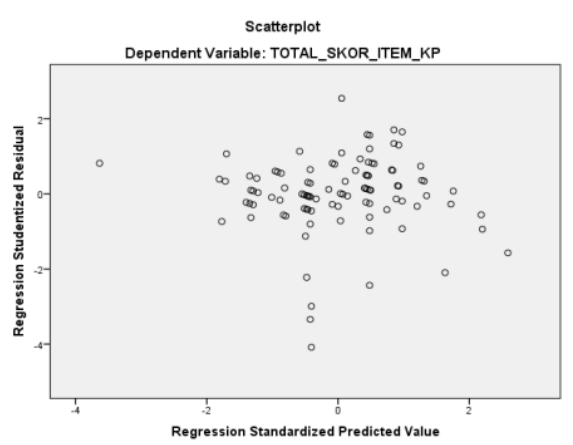

Gambar 4. Hasil Uji Heteroskedastisitas

Grafik di atas menunjukkan adanya hubungan antara variabel independent dan dependent, jika kita lihat sebaran datanya berpencar di sekitar angka nol dan tidak membentuk suatu pola atau kecenderungan tertentu, maka dengan demikian data ini telah layak memenuhi syarat heteroskedastisitas dan model regresi layak digunakan untuk memprediksi.

\section{Uji Multikolinearitas}

\section{Tabel 7. Hasil Uji Multikolinearitas} Coefficients ${ }^{\mathbf{a}}$

\begin{tabular}{|c|l|r|r|}
\multicolumn{2}{|c|}{ Model } & \multicolumn{2}{|c|}{ Collinearity Statistics } \\
\cline { 3 - 4 } & Tolerance & \multicolumn{1}{c|}{ VIF } \\
\hline \multirow{3}{*}{1} & $($ Constant) & & \\
\cline { 2 - 4 } & Promosi (X1) & 0.981 & 1.019 \\
\cline { 2 - 4 } & Harga (X2) & 0.981 & 1.019 \\
\hline
\end{tabular}

a. Dependent Variable: Keputusan Pembelian (Y)

Pengujian pada model regresi linier berganda, menunjukkan nilai Tolerance dan VIF variable $\mathrm{X}_{\mathbf{1}}$ Promosi dan Variabel $\mathrm{X}_{2}$ Harga sebesar 0.981 dan 1.019. Karena nilai Tolerance $<1$ dan hasil VIF $<10$, hal ini dapat dikatakan bahwa pada variable tidak terjadi Multikolinearitas.

\section{Analisis Regresi Linear Berganda}

Analisis regresi linear berganda digunakan untuk menganalisis besarnya pengaruh lebih dari satu variabel independen terhadap variabel dependen.
Tabel 8. Hasil Uji Regresi Linear Berganda

\begin{tabular}{|c|r|r|r|r|r|}
\hline \multirow{2}{*}{ Model } & \multicolumn{2}{|c|}{$\begin{array}{c}\text { Unstandardized } \\
\text { Coefficients }\end{array}$} & \multirow{2}{*}{ T } & \multirow{2}{*}{ Sig } \\
\cline { 3 - 6 } \multicolumn{2}{c|}{} & \multicolumn{1}{c|}{ B } & \multicolumn{1}{c|}{$\begin{array}{c}\text { Std. } \\
\text { Error }\end{array}$} & & \\
\hline \multirow{2}{*}{1} & (Constant) & 9.742 & 7.030 & 0.169 & 0.169 \\
\cline { 2 - 6 } & Promosi (X1) & -0.029 & -0.077 & -0.382 & 0.703 \\
\cline { 2 - 6 } & Harga (X2) & 0.729 & 0.124 & 5.883 & 0.000 \\
\hline
\end{tabular}

Dari hasil diperoleh persamaan regresi: $Y=9.742-0.029 X_{1}+0.729 X_{2}$

Konstanta sebesar 9.742 bernilai positif, dapat diartikan bahwa Keputusan Pembelian(Y) akan bernilai 9.742 pada saat Promosi $\left(\mathrm{X}_{1}\right)$ dan Harga $\left(\mathrm{X}_{2}\right)$ bernilai nol atau tidak ada.

Koefisien regresi Promosi $\left(\mathrm{X}_{1}\right)$ sebesar -0.029 dan bertanda negatif, ini menunjukan bahwa jika setiap kenaikan Promosi $\left(\mathrm{X}_{1}\right)$ satu persen maka Keputusan Pembelian (Y) akan terjadi penurunan Keputusan Pembelian sebesar -0.029 dengan asumsi bahwa variabel bebas yang lain dari model regresi adalah tetap atau tidak mengalami perubahan.

Koefisien regresi Harga $\left(\mathrm{X}_{2}\right)$ bernilai positif, yaituo.729menyatakan bahwa setiap kali terjadi peningkatan sebesar satu persen pada Keputusan Pembelian (Y), maka akan terjadi peningkatan Keputusan Pembelian sebesar 0.729 dengan asumsi bahwa variabel bebas yang lain dari model regresi adalah tetap atau tidak berubah.

Analisis Koefisien Determinasi Tabel 9. Hasil Uji Koefisien Determinasi

\begin{tabular}{|c|c|c|c|c|}
\hline Model & $\mathrm{R}$ & R Square & $\begin{array}{c}\text { Adjusted R } \\
\text { Square }\end{array}$ & $\begin{array}{c}\text { Std. Error } \\
\text { of the } \\
\text { Estimate }\end{array}$ \\
\hline 1 & $0.514^{\mathrm{a}}$ & 0.264 & 0.249 & 2,774 \\
\hline
\end{tabular}

a. Predictors: (Constant), Harga (X2), Promosi (X1)

b. Dependent Variable: Keputusan Pembelian (Y)

Hasil uji koefisien determinasi menunjukkan angka sebesar o,264 yang berarti bahwa konstribusi variabel Promosi dan Harga terhadap Keputusan Pembelian sebesar $26,4 \%$ sedangkan sisanya sebesar $73,6 \%$ dipengaruhi oleh faktor lain di luar kedua faktor tersebut. 


\section{Uji ji t (parsial)}

Tabel 10. Hasil Uji Signifikansi (Uji t)

\begin{tabular}{|c|c|c|c|}
\hline \multicolumn{4}{|c|}{ Coefficients $^{a}$} \\
\hline & Model & $\mathrm{t}$ & Sig. \\
\hline \multirow{3}{*}{1} & (Constant) & 1.386 & .169 \\
\hline & Promosi (X1) & 0.382 & .703 \\
\hline & Harga (X2) & 5.883 & .000 \\
\hline
\end{tabular}

a. Dependent Variable: Keputusan Pembelian (Y)

Hasil uji parsial (t) untuk variabel promosi diperoleh nilai $t_{\text {hitung }}(0,382)<t_{\text {tabel }}$ $(2,77645)$ dan signifikansi $0,703>0,05$. Yang artinya secara parsial promosi tidak berpengaruh yang signifikan terhadap keputusan pembelian.

Hasil uji parsial (t) untuk variabel harga diperoleh nilai $t_{\text {hitung }}(5,883)>t_{\text {tabel }}$ $(2,77645)$ dan signifikansi $0,000<0,05$. Yang artinya secara parsial harga berpengaruh signifikan terhadap keputusan pembelian.

\section{Uji Simultan (Uji F)}

Tabel 11. Hasil Uji Simultan (Uji F) ANOVA $^{a}$

\begin{tabular}{|l|l|r|r|r|c|c|}
\multicolumn{2}{|c|}{ Model } & \multicolumn{1}{|c|}{$\begin{array}{c}\text { Sum of } \\
\text { Squares }\end{array}$} & Df & $\begin{array}{c}\text { Mean } \\
\text { Square }\end{array}$ & F & Sig. \\
\hline 1 & $\begin{array}{l}\text { Regres } \\
\text { sion }\end{array}$ & 1,369 & 1 & 1,369 & .133 & $.717^{\mathrm{b}}$ \\
\cline { 2 - 7 } & $\begin{array}{l}\text { Residu } \\
\text { al }\end{array}$ & 1012.821 & 98 & 10,335 & & \\
\cline { 2 - 8 } & Total & 1014.190 & 98 & & & \\
\hline
\end{tabular}

a. Dependent Variable: Keputusan Pembelian (Y)

b. Predictors: (Constant), Harga (X2), Promosi (X1)

Hasil uji $\mathrm{F}$ pengaruh simultan variabel Promosi dan Hargaterhadap Keputusan Pembelian diperoleh nilai $F_{\text {hitung }}$ 0.133 dengan nilai signifikansi 0,717>0,05. Sehingga disimpulkan secara simultan promosi dan harga tidak berpengaruh signifikan terhadap keputusan pembelian pada Toko Kalkulator Citra Pasar Senen.

\section{SIMPULAN}

Berdasalkan hasil dan pembahasan dapat di simpulkan:

Secara parsial promosi tidak mempunyai pengaruh yang signifikan terhadap keputusan pembelian. Sedangkan harga mempunyai pengaruh yang signifikan terhadap keputusan pembelian. Secara simultan promosi harga tidak berpengaruh terhadap keputusan pembelian pada Toko Citra Pasar Senen.

Perlu adanya penelitian lanjutan yang dapat mengungkapkan faktor-faktor lainnya yang mempengaruh keputusan pembelian produk kalkulator.

\section{DAFTAR PUSTAKA}

Ali, Hasan. 2013. Marketing dan KasusKasus Pilihan. Yogyakarta. CAPS (Center For Academic Publishing Service).

Amiludin Lucky. 2015. Jurnal Berkala Ilmiah Efisiensi. Pengauh Kualitas Produk, Promosi Dan Store Atmosfer Terhadap Keputusan Pembelian KFC Mega Mas Manado. Vol 15 No 5 Tahun 2015.

Arikunto, S. 2013. Prosedur Penelitian : Suatu Pendekatan Praktik. Jakarta : Rineka Cipta.

Assauri, Sofjan. 2011. Manajemen Pemasaran. Jakarta : Rajawali Pers.

Daryanto. 2011. Manajemen Pemasaran : Sari Kuliah. Bandung: Satu Nusa.

Djaslim Saladin dan Herry Achmad Buchory. 2010. Manajemen Pemasaran Ringkasan Praktis, Teori, Aplikasi, dan Tanya Jawab, Linda Karya, Bandung

Efendi, Jusuf Udaya, Setiyaningrum. 2015. Prinsip - Prinsip Pemasaran. Yogyakarta : Andi.

Ekawati, Soegianto, Yudhyani. Pengaruh Harga Dan Promosi Terhadap Keputusan Membeli Air Mineral Aqua Di Samarinda.

Ekawati, Soegianto, Yudhyani. Pengaruh Harga Dan Promosi Terhadap Keputusan Membeli Air Mineral Aqua Di Samarinda. 
Fandy, Tjiptono. 2011. Service Management Mewujudkan Layanan Prima. Edisi 2. Yogyakarta : Andi.

Handoko, T. Hani. 2010. Manajemen Personalia \& Sumber daya Manusia. BPFE-Yogyakarta.

Istijanto, 2009. Aplikasi Riset Pemasaran, Jakarta : Gramedia Pustaka Utama

Kamal, Rachma Anindya. 2014. Pengaruh Harga, Lokasi, Dan Kualitas Produk Terhadap Keputusan Pembelian (Studi Kasus Pada Coffe Stove Syndicate Café Semarang). Vol 3 Mo 13 Tahun 2014.

Kamal, Rachma Anindya. 2014. Pengaruh Harga, Lokasi, Dan Kualitas Produk Terhadap Keputusan Pembelian (Studi Kasus Pada Coffe Stove Syndicate Café Semarang). Vol 3 Mo 13 Tahun 2014.

Kotler, Philip and Kevin Lane Keller. 2011. Manajemen Pemasaran, Edisi 13 Jilid 1 dan 2, Alih Bahasa : Bob Sabran, Erlangga, Jakarta.

M.A., Morissan. 2010. Periklanan Komunikasi Pemasaran Terpadu. Jakarta: Kencana.

Muanas Ahmad. 2014. Jurnal Riset Dan Ilmu. Pengaruh Produk, Harga Dan Promosi Terhadap Keputusan Pembelian Mobil Buana Indomobil Trada. Vol 3 No 1 Tahun 2014.

Muanas Ahmad. 2014. Jurnal Riset Dan Ilmu. Pengaruh Produk, Harga Dan Promosi Terhadap Keputusan Pembelian Mobil Buana Indomobil Trada. Vol 3 No 1 Tahun 2014.

Nia Aprilia. 2013. Jurnal Analisis Pengaruh Kualitas Pelayanan, Harga, Dan Promosi Terhadap Keputusan Pelanggan Dryriana Bakery Dan Cafe Pandaran. Vol 2 No 12 Tahun 2012.

Nia Aprilia. 2013. Jurnal Analisis Pengaruh

Kualitas Pelayanan, Harga, Dan

Promosi Terhadap Keputusan

Pelanggan Dryriana Bakery Dan Cafe Pandaran. Vol 2 No 12 Tahun 2012. Sugiyono, 2013, Metodelogi Penelitian Kuantitatif, Kualitatif Dan R\&D. Bandung: Alfabeta.

Wilson Setiawan. 2012. Jurnal Pengaruh Marketing Mix Terhadap Keputusan Pembelian Toyota Avanza Di Surabaya. 